\title{
Immunophenotype analysis of malignant histiocytosis of the intestine
}

\author{
DM SALTER, AS KRAJEWSKI, AE DEWAR \\ From the Department of Pathology, Edinburgh University Medical School, Edinburgh
}

SUMMARY Five cases of malignant histiocytosis of the intestine and one case of true histiocytic lymphoma were studied using immunohistological techniques. In paraffin sections tumour cells in all cases were shown to contain $\alpha-1$-antitrypsin and to express the leucocyte common antigen. Four of the five cases of malignant histiocytosis of the intestine and the case of histiocytic lymphoma expressed the epithelial membrane antigen. Cryostat sections in four cases of malignant histiocytosis of the intestine showed that most tumour cells reacted with anti-T cell monoclonal antibodies. Only a minority expressed a typical monocyte macrophage phenotype.

Malignant histiocytosis of the intestine has only recently been recognised ${ }^{1-3}$ and is being increasingly diagnosed with the aid of immunohistochemical techniques, especially in association with coeliac disease. ${ }^{4}$ As fresh tissue for immunological studies is rarely available diagnosis of this disease has relied on the recognition of variable morphological patterns and the confirmation of the presence of $\alpha$-1-anti-trypsin ( $\alpha 1 \mathrm{AT})$, a marker of histiocytic tumour cells in paraffin sections. ${ }^{5}$ The histogenesis of malignant histiocytosis of the intestine has been sparsely documented. A study of the immunological, immunohistochemical, and cytochemical properties of the cells of malignant histiocytosis of the intestine ${ }^{3}$ included only three cases, with a limited frozen section immunohistochemical analysis on only one case. A recent study of histiocytic lymphoma showed phenotypic heterogeneity within true histiocytic malignancies, with results in some cases, suggesting differentiation of the malignant histiocytes towards specialised subsets. ${ }^{6}$ This last study did not include cases of malignant histiocytosis of the intestine. The pronounced morphological heterogeneity within the neoplastic cells of cases of malignant histiocytosis of the intestine suggests that a similar immunophenotypic variation may be present. In our study we used immunoperoxidase techniques, and a large number of antisera (both monoclonal and polyclonal) were tested on cryostat and formalin fixed paraffin embedded sections from cases of malignant histiocytosis of the intestine. The results were compared with those of a case of true histiocytic lymphoma.

Accepted for publication 21 August 1985

\section{Material and methods}

Six patients were studied, five diagnosed cases of malignant histiocytosis of the intestine and one case of histiocytic lymphoma: all were positive for $\alpha 1 \mathrm{AT}$.

\section{CASE HISTORIES}

Case 1 A 71 year old woman presented as an acute abdominal emergency following a three month history of diarrhoea, vomiting, weight loss, and general malaise. She had no noteworthy medical history. At operation, extensive tumours were seen throughout the jejunum and ileum. Histology showed the presence of multiple, often superficially ulcerated tumours composed of large malignant histiocytes with irregular nuclei, prominent nucleoli, and abundant eosinophilic cytoplasm admixed with scattered lymphocytes. The non-ulcerated lengths of small intestine showed partial to subtotal villous atrophy. Malignant histiocytosis of the intestine was diagnosed. She died within three months: necropsy was not performed.

Case 2 A 62 year old man presented with a six $\stackrel{N}{\sigma}$ month history of weight loss, anorexia, diarrhoea, N and pain of the lower back. Laparotomy showed $N$ thickening of the terminal half of the ileum and enlarged mesenteric lymph nodes. Histology showed multiple nodules of tumour within the ileum and local lymph nodes composed of malignant histiocytes with irregular nuclei, prominent nucleoli, and abundant eosinophilic cytoplasm. Multinucleate forms were present. The ileum unaffected by tumour nodules showed villous atrophy. Malignant histiocytosis of the intestine was diagnosed. He died one day after the operation. At necropsy further tumour nodules 
within the unresected small intestine were seen. Liver and spleen were normal.

Case 3 A 59 year old man presented with a three month history of weight loss, general malaise, and anorexia. He had no notable medical history. A barium meal showed a defect in the jejunum, which at laparotomy was found to be an ulcerated tumour (4.5 $\mathrm{cm})$. Further tumour deposits were found within the jejunum, local lymph nodes, and liver. Histology of laparotomy specimens showed that the tumours were composed of large cells with irregular, often multilobed nuclei, showing considerable pleomorphism. Large multinucleated giant cells were prominent. The intestinal mucosa showed mild villous irregularity but no true villous atrophy. Malignant histiocytosis of the intestine was diagnosed. He died four days postoperatively: necropsy was not performed.

Case 4 A 61 year old man presented as an acute abdominal emergency with no notable medical history. Laparotomy showed a large tumour within the ileum with thickening of the adjacent intestinal wall and spread to the local lymph nodes. The excised 280 $\mathrm{cm}$ of small intestine contained an ulcer $8 \mathrm{~cm}$ in depth that occupied most the mesenteric mass with walls and base composed of tumour up to $4 \mathrm{~cm}$ deep. The adjacent ileum was thickened, but no further areas of ulceration were noted. Histologically, the tumour consisted of a rather monomorphic infiltrate of medium to large cells with irregular, slightly indented nuclei, small nucleoli, and small amounts of eosinophilic cytoplasm. The intestinal origin of the tumour was seen over a short segment of the adjacent ileum. Villous atrophy was not evident, and the ileal mucosa had minimally shortened villi, which were distended by a non-specific chronic inflammatory cell infiltrate with increased numbers of intraepithelial lymphocytes. Centrocytic lymphoma was diagnosed initially, but immunohistochemistry showed strong granular paranuclear staining for $\alpha 1$ AT. Malignant histiocytosis of the intestine was diagnosed. He died three months postoperatively: necropsy was not performed.

Table 1 Monoclonal antibodies used in this study

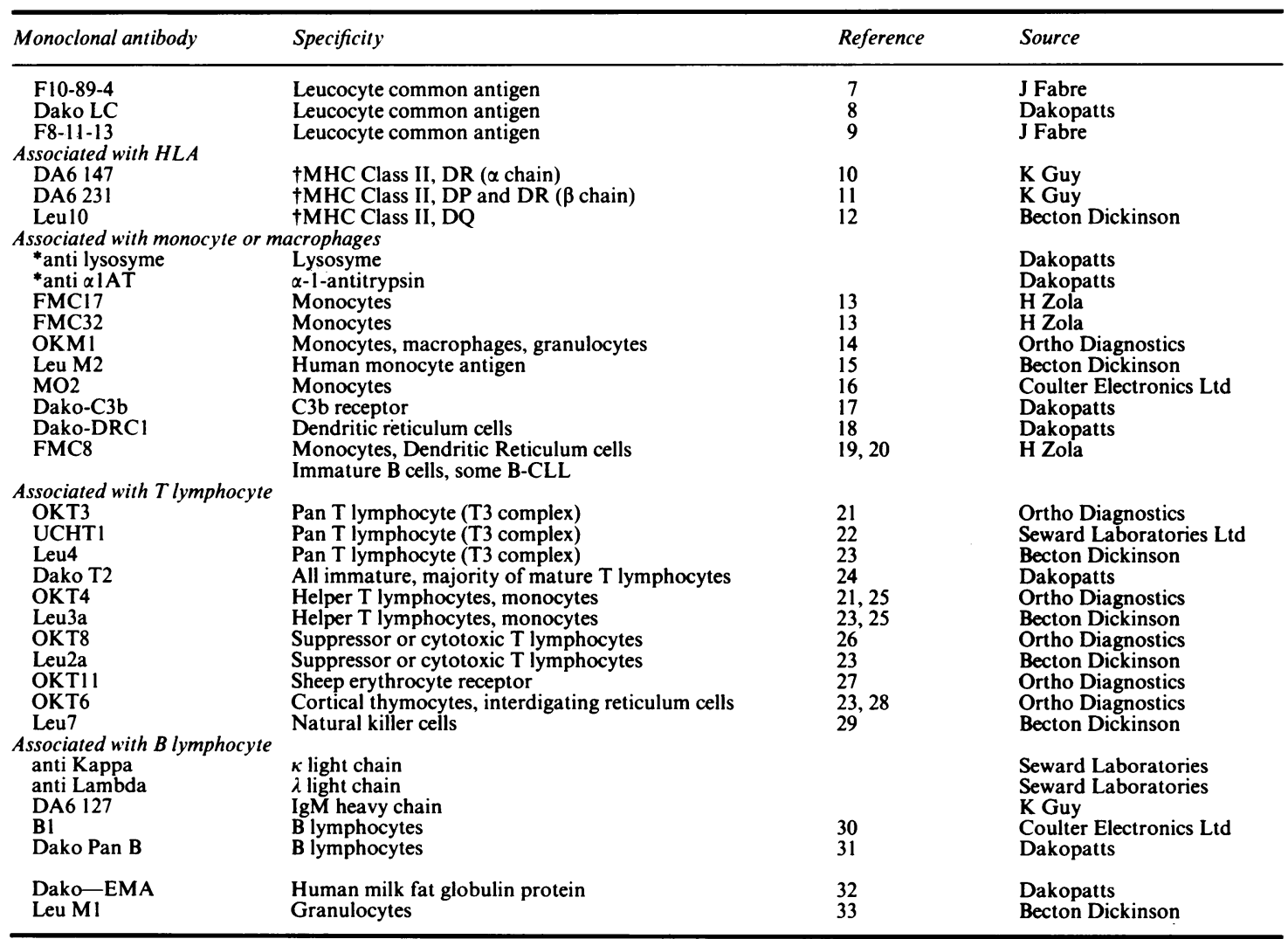

*Polyclonal antiserum.

+MHC = Major histocompatibility complex. 


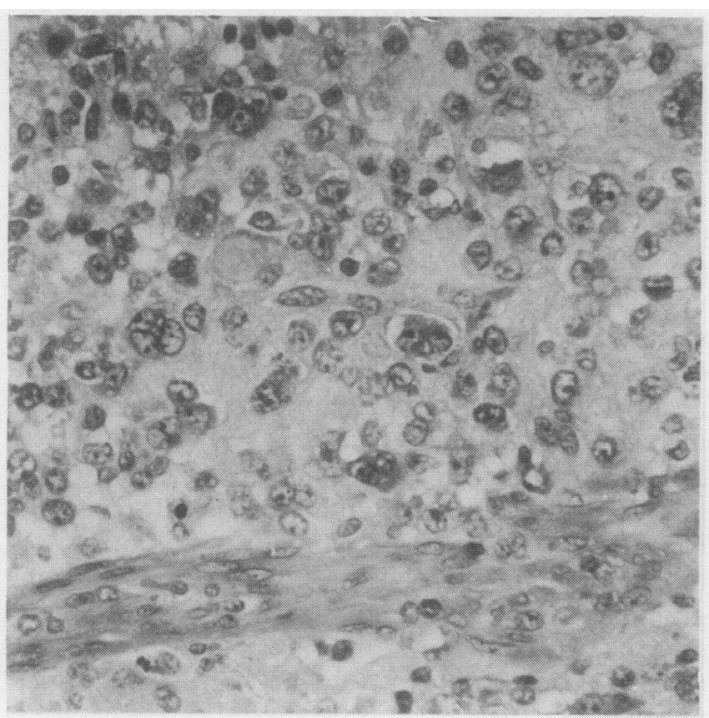

Fig. 1 Malignant histiocytosis of the intestine (case 3) showing diffuse infiltrate of large pleomorphic cells with irregular nuclei and prominent nucleoli. Multinucleated cells are present. Paraffin section, haematoxylin and eosin. $\times 250$.

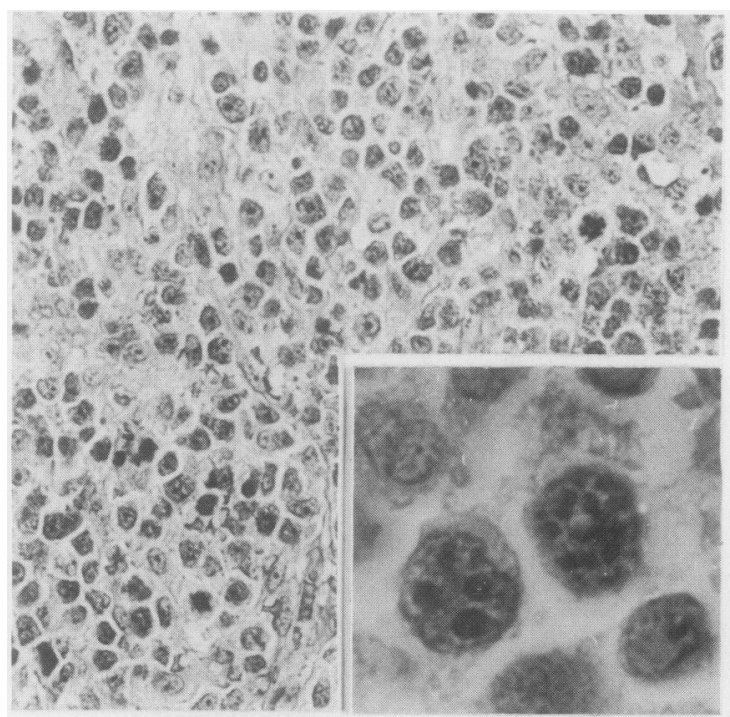

Fig. 2 Malignant histiocytosis of the intestine (case 4). Tumour consists of slightly irregular medium sized cells showing mild nuclear pleomorphism, prominent nucleoli, and mild to moderate amounts of cytoplasm. Paraffin section, haematoxylin and eosin. $\times 250$; inset $\times 1000$.

Case 5 A 45 year old woman with a long history of coeliac disease presented as an acute abdominal emergency. Laparotomy showed a perforated ileum with multiple sites of stricture and ulceration. Histology showed the presence of multiple deposits of tumour consisting of large pleomorphic histiocytes, often with multilobed nuclei and multinucleated forms. The jejunal mucosa showed severe, partial, and subtotal villous atrophy. Malignant ristiocytosis of the intestine was diagnosed.

She died six weeks postoperatively. At necropsy no evidence of further intestinal tumour, or spread to the spleen, liver, or bone marrow was found.

Case 6 A 19 year old man presented with a four week history of a swelling in the left axilla. Histology showed the presence of a highly cellular neoplasm composed of large cells with moderate cytoplasm, large vesicular nuclei, and a high mitotic rate. True histiocytic lymphoma was diagnosed after immunohistochemical studies. He was alive one month postoperatively.

TISSUE SAMPLES AND IMMUNOHISTOCHEMICAL STAINING

A panel of antibodies (Table 1) were used on both cryostat and paraffin sections by a previously described immunoperoxidase technique. ${ }^{34}$ Cryostat sections were incubated with primary monoclonal antibody at room temperature for 30 minutes; paraffin sections were incubated for 30 minutes at room temperature and stained for $\alpha 1 \mathrm{AT}$ and lysozyme and with other antisera overnight. Sections were trypsinised before staining for $\alpha 1 \mathrm{AT}$ and lysozyme.

\section{Results}

HISTOLOGY AND TUMOUR CLASSIFICATION

All five cases of intestinal neoplasm in this study were diagnosed as cases of malignant histiocytosis of the intestine based on morphological appearances after examination of paraffin sections stained with haematoxylin and eosin. ${ }^{135}$ All tissues showed characteristic granular paranuclear staining for $\alpha 1 \mathrm{AT}$.

In cases 1, 2, and 5 there was either a history of coeliac disease, or villous atrophy was seen histologically. Case 3 showed only mild villous atrophy. Multiple deposits of tumour were present in cases 1, 2, 3, and 5. The histological appearances in each of these cases were similar, the tumours consisting of large pleomorphic cells with irregular nuclei and prominent nucleoli (Fig. 1). Multinucleated forms were often present. In contrast, in case 4 only one tumour deposit was noted within the small intestine, and true villous atrophy was not a feature. Histology showed a rather monomorphic population of medium to large cells with irregular indented nuclei, small nucleoli, and small to moderate amounts of cytoplasm (Fig. 2). Although this case was initially diagnosed as a centrocytic lymphoma, the subsequent strong paranuclear staining with $\alpha 1 \mathrm{AT}$ and the similarity with the less differentiated or blastic form of histiocytic lym- 
Table 2 Immunohistochemical staining of paraffin sections

\begin{tabular}{|c|c|c|c|c|c|c|c|}
\hline \multirow[t]{2}{*}{ Case No } & \multirow[t]{2}{*}{ Diagnosis } & \multicolumn{6}{|c|}{ Antibody } \\
\hline & & $\overline{\alpha l A T}$ & Lysozyme & F8-11-13 & Dako LC & Dako-EMA & $\overline{L e u} M I$ \\
\hline $\begin{array}{l}1 \\
2 \\
3 \\
4 \\
5 \\
6\end{array}$ & $\begin{array}{l}\text { MHI } \\
\text { MHI } \\
\text { MHI } \\
\text { MHI } \\
\text { MHI } \\
\text { HL }\end{array}$ & $\begin{array}{l}+ \\
+ \\
++ \\
++ \\
++ \\
+++\end{array}$ & $\begin{array}{l}+ \\
+ \\
- \\
- \\
-\end{array}$ & $\begin{array}{l}+ \\
+ \\
+++ \\
+++ \\
++ \\
-\end{array}$ & $\begin{array}{l}+++ \\
+++ \\
+++ \\
+++ \\
+++ \\
++\end{array}$ & $\begin{array}{l}++ \\
+ \\
+ \\
+ \\
+ \\
+++\end{array}$ & $\begin{array}{l}- \\
\overline{-} \\
- \\
- \\
-\end{array}$ \\
\hline
\end{tabular}

Negative $(-)=<10 \%$; mildly positive $(+)=10-30 \%$; strongly positive $(++)=30-60 \%$; very strongly positive $(+++)=>60 \%$ positively reacting tumour cells.

$\mathrm{MHI}=$ Malignant histiocytosis of the intestine; $\mathrm{HL}=$ histiocytic lymphoma.

phoma, recognised by Isaacson and Wright, ${ }^{36}$ resulted in a review diagnosis of malignant histiocytosis of the intestine.

True histiocytic lymphoma was definitively diagnosed in case 6 but only with the aid of immunohistochemical studies.

\section{IMMUNOHISTOCHEMICAL STAINING OF PARAFFIN SECTIONS}

All the paraffin sections were stained with various antisera that react with tissue fixed in formalin. Table 2 shows the results.

In all five cases of malignant histiocytosis of the intestine and in the one case of histiocytic lymphoma tumour cells reacted with $\alpha 1 \mathrm{AT}$, although the intensity of the staining reaction between individual cells and the number of malignant cells staining within the specimens varied.

Only two of our cases showed staining for lysozyme in tumour cells (cases 1 and 2), and this is consistent with a previous report in which only a few cases of malignant histiocytosis of the intestine stained for lysozyme. ${ }^{5}$

The haemopoietic origin of the malignant cells was shown by reactivity with the leucocyte common antibodies. All six cases reacted strongly with Dako leucocyte common, a mixture of two monoclonal antibodies against different determinants on the leucocyte common antigen. ${ }^{9}$ F8-11-13, which recognises the high molecular weight form of the leucocyte common antigen, ${ }^{7}$ reacted strongly with three cases of malignant histiocytosis of the intestine (cases 3, 4, and 5) and reacted weakly with the two other cases. F8-11-13 did not react with the histiocytic lymphoma.

Five of the six cases reacted with epithelial membrane antigen (Dako), producing both a strong membrane and a focal cytoplasmic reaction. These findings are consistent with the observation of other workers who have shown reactivity of monoclonal antibodies against the human milk fat globule protein with histiocytic neoplasms and a proportion of cases of non-Hodgkin's lymphoma. ${ }^{37}$ None of the cases reacted with Leu M1, which primarily detects granu- locytes but which has recently been shown to react with Reed Sternberg and Hodgkin's cells. ${ }^{37} 38$

\section{IMMUNOHISTOCHEMICAL STAINING OF}

\section{CRYOSTAT SECTIONS}

Fresh frozen tissue was available from four of the cases of malignant histiocytosis of the intestine and from the case of histiocytic lymphoma. Table 3 gives the results of staining with a panel of monoclonal antibodies.

Reactivity with the leucocyte common antibodies F10-89-4 and Dako leucocyte common show that the tumour cells are of haemopoietic origin. Results with Dako leucocyte common and F8-11-13 were comparable with those seen with paraffin sections.

Expression of monocyte markers by tumour cells was variable. In each of the cases of malignant histiocytosis of the intestine studied a proportion of tumour cells showed reactivity with three of the panel

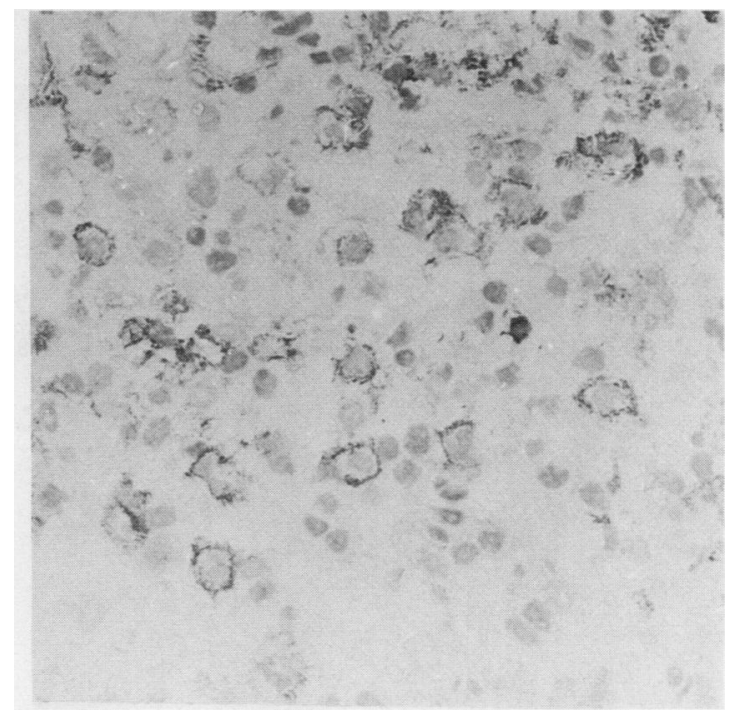

Fig. 3 Malignant histiocytosis of the intestine (case 3) stained with FMC 17. Proportion of tumour cells show strong membrane immunoreactivity. Cryostat section. $\times 400$. 
Table 3 Immunohistochemical staining on frozen section

\begin{tabular}{|c|c|c|c|c|c|}
\hline \multirow[t]{2}{*}{ Monoclonal antibody } & \multicolumn{5}{|c|}{ Case No and diagnosis } \\
\hline & $\begin{array}{l}\text { (1) } \\
M H I\end{array}$ & $\begin{array}{l}(2) \\
M H I\end{array}$ & $\begin{array}{l}(3) \\
M H I\end{array}$ & $\begin{array}{l}(4) \\
M H I\end{array}$ & $\begin{array}{l}\text { (6) } \\
H L\end{array}$ \\
\hline F10-89-4 & $+t+$ & $+t+$ & $+t+$ & $+t+$ & $+t+$ \\
\hline DAKO Lc & $+t+$ & $t+t$ & $+t+$ & $+t+$ & $+t+$ \\
\hline F8-11-13 & + & + & $+t+$ & $+t+$ & - \\
\hline DA6 147 & $+t$ & + & - & ++ & + \\
\hline DA6 231 & $+t+$ & $+t+$ & $+t$ & $+t$ & $+t+$ \\
\hline Leu10 & ++ & ++ & - & - & $+t+$ \\
\hline FMC17 & $+t$ & + & $+t$ & $+t$ & + \\
\hline FMC32 & ++ & ++ & $+t$ & $+t$ & + \\
\hline OKM 1 & $+t+$ & $+t+$ & $+t$ & $+t$ & $++t$ \\
\hline Leu M2 & - & - & - & - & $+t+$ \\
\hline $\mathrm{MO} 2$ & - & - & - & - & - \\
\hline Dako C3b & - & - & - & - & - \\
\hline Dako DRCl & - & - & - & - & - \\
\hline FMC8 & - & + & +++ & +++ & $+t$ \\
\hline OKT3 & - & + & - & + & NT \\
\hline UCHT1 & $+t$ & $++t$ & $++t$ & +++ & - \\
\hline Leu4 & $+t$ & $+t+$ & +++ & +++ & - \\
\hline Dako T2 & ++ & ++ & $+t+$ & $++t$ & - \\
\hline OKT4/Leu3a & ++ & ++ & ++ & ++ & $+t$ \\
\hline OKT8/Leu2a & - & - & - & - & - \\
\hline OKT11 & ++ & + & + & - & - \\
\hline OKT6 & - & - & - & - & - \\
\hline Leu7 & NT & NT & - & - & NT \\
\hline$\kappa$ or $\lambda$ & - & - & - & - & - \\
\hline DA6 147 & - & - & - & - & - \\
\hline B1/Dako-pan B & - & - & - & - & - \\
\hline
\end{tabular}

Negative $(-)=<10 \%$; mildly positive $(+)=10-30 \%$; strongly positive $(++)=30-60 \%$; very strongly positive $(+++)=>60 \%$ positively reacting tumour cells; NT $=$ not tested.

$\mathrm{MHI}=$ Malignant histiocytosis of the intestine; $\mathrm{HL}=$ histiocytic lymphoma.

of the monocyte macrophage monoclonal antibodies. All tissue sections contained a proportion of tumour cells that stained with the monoclonal antibodies

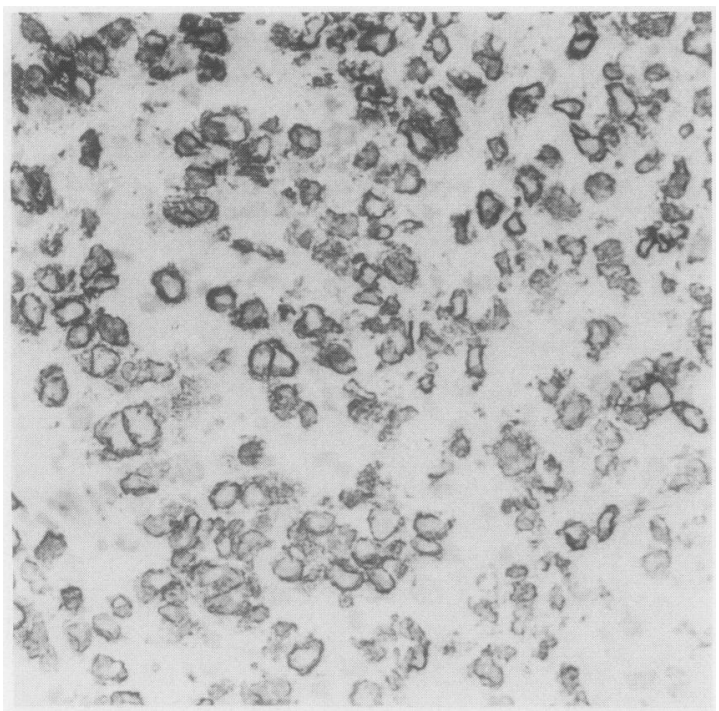

Fig. 4 Malignant histiocytosis of the intestine (case 3) stained with Leu4. Most of the large infiltrating tumour cells show strong immunoreactivity. Cryostat section, $\times 400$.
FMC17, FMC32, and OKM1 (Fig. 3) but that did not react with the antimonocyte monoclonal antibodies $\mathrm{MO} 2$ and Leu M2, or with monoclonal antibodies reacting with dendritic cell populations (Dako-C3b, Dako-DRC1, and OKT6). FMC8 stained most tumour cells in cases 3 and 4 and a few cells in case 2. Although FMC8 stains follicle centre dendritic reticulum cells in normal tissue (personal observation), this antibody cannot be thought of as lineage specific as it also stains immature B cells in some cases of B-chronic lymphatic leukaemia, as well as platelets, granulocytes, and monocytes. ${ }^{1920}$ The histiocytic lymphoma showed reactivity with $\mathrm{FMC17}$, FMC32, OKM1, Leu M2, and FMC8.

The staining of malignant histiocytosis of the intestine with $T$ cell monoclonal antibodies again showed variable reactivity. All tissue sections reacted with the anti T4 monoclonal antibodies Leu $3 a$ and OKT4 as did the histiocytic lymphoma. Both of these monoclonal antibodies react with cells of monocyte macrophage lineage. ${ }^{25}$ Morphologically abnormal tumour cells, however, also reacted with other $\mathrm{T}$ cell monoclonal antibodies. A large proportion of tumour cells in all cases reacted with monoclonal antibodies detecting epitopes on the T3 complex (UCHT1 and Leu 4) (Figs. 4 and 5), and they also stained with Dako T2, which reacts with a $T$ cell associated antigen. ${ }^{24}$ Only two cases ( 2 and 4 ) showed reactivity 


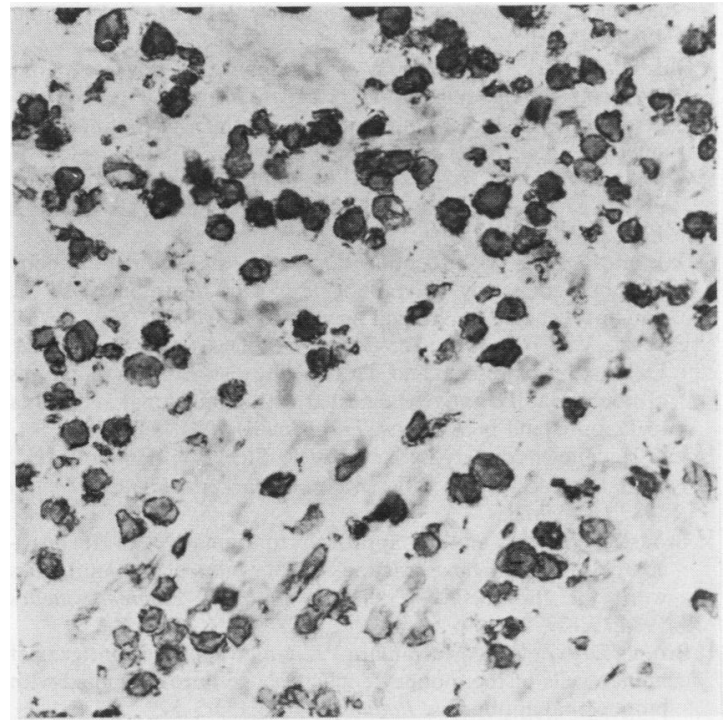

Fig. 5 Malignant histiocytosis of the intestine (case 4) stained with Leu4. Leu4 is reacting strongly with most of the tumour cells. Cryostat section. $\times 400$.

with OKT3. A few tumour cells in cases 1,2 , and 3 reacted weakly with OKT11. None of the cases reacted with the anti T8 monoclonal antibodies. Neither of the two cases tested reacted with Leu 7, an antibody which recognises natural killer cells. In serial sections a proportion of tumour cells reacting with $\mathrm{T}$ cell monoclonal antibodies also seemed to react with OKM1. The histiocytic lymphoma reacted with the anti T4 monoclonal antibodies but did not react with any of the other $\mathrm{T}$ cell monoclonal antibodies used.

There was variable expression of Class II major histocompatibility complex antigens. In cases 1 and 2 DR $(\alpha$ and $\beta$ ) and DQ antigens were detectable (DA6 231, DA6 147, and Leu 10, respectively). In cases 3 and 4 a few tumour cells expressing DR antigens could be detected, but tumour cells expressing DQ were not seen. The histiocytic lymphoma expressed DR $(\alpha$ and $\beta$ ) and DQ antigens. None of the cases reacted with the pan B lymphocyte markers Dako B, $B 1$, or with the monoclonal antibodies to immunoglobulin light or IgM heavy chains.

\section{Discussion}

Each of the five cases of intestinal malignancy in this study exhibited clinical features and histological appearances, including strong paranuclear staining for $\alpha 1 \mathrm{AT}$, which led to the clinicopathological diagnosis of malignant histiocytosis of the intestine based on the criteria described by Isaacson and Wright, ${ }^{135}$ In case 4 some features differed from the other cases but this case was similar morphologically to the blastic or poorly differentiated form of histiocytic lymphoma recognised by Isaacson and Wright. ${ }^{36}$

Reactivity of all five cases with leucocyte common antibodies confirms the haemopoietic lineage of the tumour cells. Both Dako leucocyte common and F10-89-4 react with cells of monocyte or macrophage lineage. ${ }^{78}$ F8-11-13, however, which reacts with the high molecular weight form of the leucocyte common antigen expressed by $B$ cells and only a proportion of $T$ cells ${ }^{9}$ and which does not react with cells of histiocytic lineage, ${ }^{40}$ showed reactivity within our cases. This raises questions as to the histogenesis of these tumours.

Further questions as to the histogenesis of the tumours are raised by the observations that all the tumours strongly expressed some $T$ cell markers. The finding that a proportion of tumour cells in all four cases of malignant histiocytosis of the intestine and the histiocytic lymphoma reacted with the monoclonal antibodies OKT4 and Leu3a is not unexpected as these antibodies have been shown previously to react with cells of monocyte or macrophage lineage. ${ }^{25}$ Morphologically abnormal cells, however, also expressed antigens of the $\mathrm{T} 3$ complex $\left(\mathrm{OKT} 3^{+}\right.$, $\mathrm{UCHT}^{+}, \mathrm{Leu}^{+}{ }^{+}$) and the $\mathrm{T}$ cell associated antigen recognised by Dako $T 2$, as well as reacting with OKM1.

Although clinical history, morphological criteria, and staining for $\alpha 1 \mathrm{AT}$ showed that all cases were similar and could be diagnosed as malignant histiocytosis of the intestine, the results of immunohistochemical staining showed that the tumour cells of malignant histiocytosis of the intestine did not express a characteristic monocyte or macrophage phenotype. The immunophenotype of most cells in our cases would be the same as those of a T cell neoplasm with a background population of cells of macrophage lineage. It could be argued that cells with a monocyte or macrophage phenotype were the "true" malignant population with $T$ cells a reactive component. Obvious abnormal cells did stain for $\alpha 1 \mathrm{AT}$ in paraffin sections; similar large multilobulated and multinucleated forms which could be identified in cryostat sections, however, reacted with $\mathrm{T}$ cell monoclonal antibodies.

Alpha 1AT is believed to be a reliable marker of malignant histiocytes. ${ }^{5}$ Recently, however, Stein et al reported a group of large cell lymphomas, positive for $\alpha 1 \mathrm{AT}$ and $\mathrm{Ki}$ 1, a proportion of which also expressed $T$ cell markers. ${ }^{24}$ These tumours bear immunophenotypic similarities to the present cases. $\mathrm{Ki} 1$ also reacts with Hodgkin's and Reed-Sternberg cells, ${ }^{2441}$ and $\alpha 1 \mathrm{AT}$ has also been reported to stain these cells. ${ }^{41}$ This raises the possibility that there may be a relation between malignant histiocytosis of the intestine and Hodgkin's disease. None of our cases reacted with Leu M1, however, whereas most Reed- 
Sternberg cells express this marker. ${ }^{38} 39$

Recently, a patient with an abnormal expansion of granular lymphocytes that reacted with both $\mathrm{T}$ cell and macrophage markers $\left(\mathrm{Leu} 7^{+}, \mathrm{OKT}^{+}, \mathrm{OKT} 4^{+}\right.$, $\mathrm{OKT}^{-}, \mathrm{OKM}^{+}$) was described. ${ }^{42}$ Although none of our specimens reacted with Leu7 when tested, the neoplastic cells in malignant histiocytosis of the intestine may possibly be related to such a cell expressing markers of $T$ cell and macrophage lineage. Such an expansion of large granular lymphocytes, which were negative for Leu7 but positive for $T$ and monocytic antigens, has been described in a patient. ${ }^{43}$

Isaacson et al recently reported four cases of malignant histiocytosis of the intestine arising in coeliac disease, each of which showed a $T$ cell phenotype. Three of these four cases also showed $T$ cell receptor gene rearrangement. ${ }^{44}$ These findings, along with our results, strongly support the idea that malignant histiocytosis of the intestine is a $\mathrm{T}$ cell lymphoma.

When a panel of monoclonal antibodies was applied to cases of malignant histiocytosis of the intestine, we obtained results that revealed a diversity of phenotype expression within the tumour cells. These results show a mixed population of cells in malignant histiocytosis of the intestine, only a proportion of which expressed typical macrophage markers, while most tumour cells expressed $T$ cell markers. These observations confirm the need for a critical re-evaluation of the histogenesis in this group of tumours.

We thank Mr D Cossar and Mr E Miller for expert technical help, the physicians of the East of Scotland and Newcastle Lymphoma Group for the clinical information on the cases studied, and Mrs Fiona Govan and Mrs Margo Boyle for typing the manuscript.

This work was in part supported by grants from the Melville Trust and the Sir Stanley and Lady Davidson Research Fund.

\section{References}

' Isaacson P, Wright DH. Malignant histiocytosis of the intestine. Its relationship to malabsorption and ulcerative jejunitis. Hum Pathol 1978;9:661-77.

${ }^{2}$ Isaacson P, Wright DH. Intestinal lymphoma associated with malabsorption. Lancet 1978; ;:67-70.

${ }^{3}$ Isaacson P, Jones DB, Sworn MJ, Wright DH. Malignant histiocytosis of the intestine: report of three cases with immunological and cytochemical analysis. $J$ Clin Pathol 1982;35:510-6.

${ }^{4}$ Swinson CM, Slavin G, Coles EC, Booth CC. Coeliac disease and malignancy. Lancet 1983;i:111-5.

${ }^{5}$ Isaacson PG, Jones DB. Immunohistochemical differentiation between histiocytic and lymphoid neoplasms. Histochem $J$ 1983;15:621-35.

${ }^{6}$ Turner RR, Wood G, Beckstead JH, Colby TV, Horning SJ, Warnke RA. Histiocytic malignancies, morphologic, immu- nologic and enzymatic heterogeneity. Am J Surg Pathol 1984;8:485-500.

${ }^{7}$ Dalchau R, Kirkley J, Fabre JW. Monoclonal antibody to a human leucocyte-specific membrane glycoprotein probably homologous to the leucocyte-common (L-C) antigen in the rat. Eur $J$ Immunol 1980;10:737-44.

${ }^{8}$ Warnke RA, Gatter KC, Falini B, et al. Diagnosis of human lymphoma with monoclonal antileukocyte antibodies. $N$ Engl J Med 1983;309:1275-81.

${ }^{9}$ Dalchau R, Fabre JW. Identification with a monoclonal antibody of a predominantly B lymphocyte-specific determinant of the human leucocyte common antigen. J Exp Med 1981;153:755-65.

${ }^{10}$ Guy K, Van Heyningen V, Cohen BB, Deane DL, Steel CM. Differential expression and serologically distinct subpopulations of human Ia like antigens detected with monoclonal antibodies to Ia alpha and beta chains. Eur $J$ Immunol 1982;12:942-8.

${ }^{11}$ Van Heyningen V, Guy K, Newman R, Steel CM. Human MHC class II molecules as differentiation markers. Immunogenetics 1982;16:459-69.

${ }^{12}$ Brodsley FM. A mature approach to human class II histocompatibility antigens; reactions of four monoclonal antibodies with the products of nine haplotypes. Immunogenetics 1984;19:179-84.

${ }^{13}$ Brooks DA, Zola H, McNamara PJ, et al. Membrane antigens of human cells of the monocyte/macrophage lineage studied with monoclonal antibodies. Pathology 1983;15:45-52.

${ }^{14}$ Breard JM, Rheinhertz EL, Kung PC, Goldstein G, Schlossman SF. A monoclonal antibody reactive with human peripheral blood monocytes. J Immunol 1980;124:1943-8.

${ }^{15}$ Raff HV, Picker LJ, Stobo JD. Macrophage heterogeneity in man: a subpopulation of HLA Dr bearing macrophages required for antigen-induced T-cell activation also contains stimulators for autologous reactive T cells. J Exp Med 1980;152:581-93.

${ }^{16}$ Todd RF III, Nadler LM, Schlossman SF. Antigens on human monocytes identified by monoclonal antibodies. I Immunol 1981;126:1435-42.

${ }^{17}$ Gerdes J, Naiem M, Mason DY, Stein H. Human complement (C3b) receptors defined by a mouse monoclonal antibody. Immunology 1982;45:645-53.

${ }^{18}$ Naiem M, Gerdes J, Modulaziz Z, Stein W, Mason DY. Production of monoclonal antibody reactive with human dendritic reticulum cells and its use in the immunohistochemical analysis of lymphoid tissue. J Clin Pathol 1983;36:167-75.

${ }^{19}$ Brooks DA, Bradley J, Zola H. A differentiation antigen expressed selectively by a proportion of human blood cells, detection with a monoclonal antibody. Pathology 1982;14:5-11.

${ }^{20}$ McKenzie IFC, Zola H. Monoclonal antibodies to B cells. Immunology Today 1983;4:10-5.

${ }^{21}$ Rheinherz EL, Kung PC, Goldstein G, Levey RH, Schlossman SF. Discrete stages of human intrathymic differentiation: analysis of normal thymocytes and leukemic lymphoblasts of $\mathrm{T}$ cell lineage. Proc Natl Acad Sci USA 1980;77:1588-92.

${ }^{22}$ Beverley PCL, Callard RE. Distinctive functional characteristics of human " $T$ " lymphocytes defined by $E$ rosetting or a monoclonal anti-T cell antibody. Eur J Immunol 1981;11:329-34.

${ }^{23}$ Ledbetter JA, Evans RC, Lipinski M, Cunningham-Rundles C, Good RA, Herzenberg LA. Evolutionary conservation of surface molecules that distinguish $T$ lymphocyte helper/inducer and $T$ cytotoxic suppressor subpopulations in mouse and man. $J$ Exp Med 1981;153:310-23.

${ }^{24}$ Stein H, Lennert K, Feller AC, Mason DY. Immunohistological analysis of human lymphoma: correlation of histological and immunological categories. Adv Cancer Res 1984;42:67-147.

${ }^{25}$ Wood GS, Warner NL, Warnke RA. Anti-Leu3/T4 antibodies react with cells of monocyte/macrophage and Langerhans lineage. J Immunol 1983;131:212-6.

${ }^{26}$ Reinherz EL, Kung PC, Goldstein C, Schlossman SF. A monoclonal antibody reactive with the human cytotoxic/suppressor $\mathrm{T}$ cell subset, previously defind by a heteroantiserum termed TH- 2 . $J$ Immunol 1980;124:1301-7. 
${ }^{27}$ Verbi W, Greaves MF, Schneider C, et al. Monoclonal antibodies OKT11 and OKT1la have pan T activity and block sheep erythrocytes "receptors". Eur J Immunol 1982;12:81-6.

${ }^{28}$ Murphy GF, Bahn AR, Sato S, Mihn MC Jr, Harrst TJ. A new immunologic marker for human Langerhans cells. $N$ Engl J Med 1981;304:791-2.

${ }^{29}$ Abo T, Balch CM. A differentiation antigen of human NK and $\mathrm{K}$ cells identified by a monoclonal antibody (HNK-7). $J$ Immunol 1981;127:1024-9.

${ }^{30}$ Nadler LM, Stashenko P, Ritz J, Hardy R, Pesando JM, Schlossman SF. A unique cell surface antigen identifying lymphoid malignancies of $\mathrm{B}$ cell origin. $J$ Clin Invest 1981;67:134-40.

${ }^{31}$ Stein $\mathbf{H}$, Gerdes J, Mason DY. The normal and malignant germinal centre. Clin Haematol 1982;11:531-59.

${ }^{32}$ Heyderman E, Steele K, Ormerod MG. A new antigen on the epithelial membrane: its immunoperoxidase localisation in normal and neoplastic tissue. J Clin Pathol 1979;32:35-9.

${ }^{33}$ Hanjan SWS, Kearney JF, Cooper MD. A monoclonal antibody (MMA) that identifies a differentiation antigen on human myelomonocytic cells. Clin Immunol Immunopathol 1982;231:172-88.

${ }^{34}$ Salter DM, Krajewski AS, Dewar AE. Immunohistochemical staining of non-Hodgkin's Lymphoma with monoclonal antibodies specific for the leucocyte common antigen. J Pathol 1985;146:345-53.

${ }^{35}$ Wright DH, Isaacson PG. Biopsy pathology of the lymphoreticular system. London: Chapman and Hall, 1983:278-84.

${ }^{36}$ Berard CW, Isaacson PG, Neiman RS, et al. Symposium on histiocytic or large cell lymphomas. In: Sommers SC, Rosen PP, eds. Malignant lymphomas: a pathology annual monograph. Norwalk. Connecticut: Appleton-Century-Crofts, 1983:109-68.

${ }^{37}$ Delsol G, Gatter KC, Stein H, et al. Human lymphoid cells express epithelial membrane antigen. Lancet 1984;ii:1124-8.

${ }^{38}$ Hsu S-M, Jaffe ES. Leu MI and peanut agglutinin stain the neoplastic cells of Hodgkin's disease. Am J Clin Pathol 1984:82:29-32.

${ }^{39}$ Pinkus GS, Said JW. Hodgkin's disease, lymphocyte predominant type, nodular-a distinct entity? Am J Pathol 1985:118:1-6.

${ }^{40}$ Stein H, Lennert K, Mason DY, Liangru S, Ziegler A. Immature sinus histiocytes: their identification as a novel $B$ cell population. Am J Pathol 1984:117:44-52.

${ }^{41}$ Stein H, Gerdes J, Schwab U, et al. Identification of Hodgkin and Sternberg-Reed cells as a unique cell type derived from a newly detected small cell population. Int $J$ Cancer 1982;30:445-59.

${ }^{42}$ Quinti I, Pacilli L, Zola V, et al. Unusual phenotype (Leu $7^{+}$, $\mathrm{OKT}^{+}, \mathrm{OKMl}^{+}$) expressed by cells from a patient with an abnormal expression of granular lymphocytes. Acta Haematol 1984:71:310-5.

${ }^{43}$ Pandolfi F, Semenzato G, De Rossi G, et al. HNK-1 monoclonal antibody (Leu7) in the identification of abnormal expansions of large granular lymphocytes. Clin Exp Immunol 1983;52:641-7.

${ }^{44}$ Isaacson PG, O'Connor NTJ, Spencer J, et al. Malignant histiocytosis of the intestine: a $\mathrm{T}$ cell lymphoma. Lancet 1985;ii:688-91.

Requests for reprints to: Dr D Salter, Department of Pathology, University Medical School, Teviot Place, Edinburgh EH8 9AG, Scotland. 